\title{
Biyanaam: A unique element of Assamese Culture; Understanding, Discussion and Preservation
}

\author{
Lotika Saikia \\ Assistant Professor, Department of Assamese, Furkating College, Golaghat
}

\begin{abstract}
:
Folk literature has come to be identified as one of the priceless resources of an indigenous community. Folk literature is an important carrier of culture, heritage and tradition of a particular cultural or linguistic community. In this context, Assamese „Biyanaam" are one type of Folk literature which falls into this mentioned description. The biyanam presented during such ceremonies reflect the socio-cultural life of the Assamese community. This trend showcases the myths, outfits, jewellery, food habits, the cultural ethos etc. This folk songs are called 'Biyanaam' (Marriage songs) as they are sung or played only on occasions of marriage ceremony. Rather it is the reflection of collective emotions as well as collective consciousness of Assamese people surfacing as or in the form of oral literature. It transforms and travels along with the changing currents of time. The „biyanaam“e or "wedding songs" sung in a traditional Assamese wedding ceremony is an integral part of Assamese culture. An Assamese wedding household is practically incomplete without these wedding songs that are sung throughout various ceremonies by the ladies present there.
\end{abstract}

Keywords:

Biyanaam, Assamese Culture, Tradition, Preservation, Reflection.

Article Received: 18 October 2020, Revised: 3 November 2020, Accepted: 24 December 2020

\section{Introduction:}

Literature encapsulates the materialistic possessions of individuals and bears it within the lone of its heart. These possessions are what we call Folklore and Literature. Even before the introduction of written scripts, folk culture and literature was spread through oral tradition. With the passage of time it acquired the written form. Assamese culture is enriched with folklore and literature. Assamese folk literature can be categorized into three major divisions-
a) Folk Songs
b) Proverbs and Quotation, and
c) Folklore

Among these, the folk songs that are performed various occasions can be considered as a subgenre. "Biyanaam", can be considered as an instance. The folksong presented during marriage ceremonies is Biyanam. Marriages are considered to be a holy and auspicious occasion. The biyanam presented during such ceremonies reflect the socio-cultural life of the Assamese society. Thus, this trend showcases the myths, outfits, food habits, the cultural ethos etc. this discussion, thereby, would encompass the traditional Assamese culture, its elements and would also try to analysis the ways to conserve it. The space that this sub-genre occupies is wide ranged. It is not possible to discuss such a wide ranged topic in a single research paper. But our discussion would not cover those areas and would only remain confined to the biyanaam sung in the Assamese language.

\section{Aims and Objectives:}

a) It will try to analysis how biyanaam represents the Assamese culture.

b) With the mention of the various perspectives of biyanaam, this discussion on folk literature and its conservation, will try to bring forth its various possible outcomes.

\section{Discussions:}

\section{Assamese Traditional Social System:}

If we look into the social structure of Assamese society, we would find that there is a 
concept of joint-family system which exists since earliest time. Even though this concept of jointfamily structure has changed in present times yet in Assamese Tradition, an ideal family would always mean or consists of Father, Mother, Sister, Brother, Uncle, Aunt etc. The sustenance of values like love, faith, affections, respect and understanding are considered as the key elements of any ideal family or "Adarsh Familye in the domain of Assamese society. Therefore, this nature of family values or social system gets its recognition in Assamese marriage songs as well

MararholoniHahurokpaba

\section{DeutarorholoniHohurukpaba}

DeutarorSwardhakhinihohurukdiba

VayerarholoniDeworakpaba

Nijorvaitirdoremoromkoriba.

In Assamese society married women have to veil /cover/ pardah their face for the sake of tradition. If she wants to come out in front of the elder people then she must veil her face, and if she reluctant to do this then it is treated as an act of dishonor to that elderly person. There is also a tradition wherein the Mother-in-Law also has to veil her face in front of the Son-in-Law. This idea has been described in the following marriage song

\section{JuwaikAdoriboloi}

\section{HahurekAhise}

MuroteUroniLoi

\section{Beliefs and Customs:}

We know that each and every indigenous community has its own set of beliefs regarding certain things. These are the part of their day-today life activity. They did these things with love and interest. Assamese society is not different from this. They maintained various beliefs and customs and accordingly the Marriage songs which are discussed here also form an important part of their beliefs and customs-

\section{UlaiAahaAaideoMatitMangol Sai}

GonokeGonita Kore Khyon Sari Jai

In Assamese society, people believe Peacock as symbolic of Goodwill bird. Therefore there is a practice of fanning the groom on the marriage day with a fan prepared via the wings of peacock bird. Amongst these, there are also various traditions which are followed by the Assamese community like the rituals of exchanging Temi-Kotari by the bride and groom which is followed by another event called Khubakhubi, which is a function organised on the third day of marriage. There is again another tradition which relates with Marriage is JURUN ceremony which is observed before the Marriage ceremony takes place. During this particular occasion, many things are offered to the family household of the bride by the groom's family. This is done out of the belief that this practice would work as a blessing for the newly-wed couple to possess or bear children in their conjugal life. Moreover, in order to increase the fertility of the newly married woman, there is a ritual of looking into Vorun tree immediately after taking bath. This can be explained in the following lines

Ga DhuiAaideoeKoloikenasabaaei Ram VorunBiriholoisabahee

VorunBirihote hate nologabaaei Ram

OlopoteJononihobahee.

Assamese traditional outfits in 'Biyanaam':

Attires not only enshroud our bodies but also projects the ethnic cultures of indigenous groups. Assamese attire is also rich in reflecting their own cultural essence. The female attires are chadar, mekhela, riha etc. the term "Assamese outfits $^{\text {ee }}$ reminds one of the "Paate, "Mugace, „Mejangkoriee, and many more famous cloths produced in the valley. Assamese weavers can depict their dreams in their hand woven cloths magnificently. Moreover, pat muga and such are produced in Assam indigenously. Assamese attires are rich with handloom works like pat muga, mejangkori, dohibota, bon-kora, guna kora, buta-bosa, kesbosa, etc. Pat muga and mejangkori are held in high regard in Assamese culture and these are some important objects of clothing in Assamese weddings to be worn by the Bride and the Groom.

\section{Kokalsai anise Kingkhapor Mekhela Gaasai anise Chula Anise RihaagotGuti bosa}




\section{Chadar amisepari bosa}

Assamese traditional jewellery in 'Biyanaam':

Jewellery came to the forth along with the introduction of beauty as an inseparable part of human existence. In ancient days people used various flowers and leaves to decorate themselves. Later on man started to shape metals like silver, gold, copper, iron and such to use as ornaments. The perceptions of people on the basis of community, culture, environment, belief may alter the places of the human body where these ornaments are adorned. The ornaments take their shape from the natural symbols- flowers, birds, trees, moons that are widely used within the community. Thereby a community's fundamental

\section{KanotMinakoradingitGolepota}

HatotMuthiKharulage

JethipotiaSorainejiaAngulitAngothilage

\section{Instruments:}

Assamese traditional instruments have its indigenous elements. Assamese community is rich not only in its use but also in its practices from time to time. In modern view, we can distinguish into four parts of these traditional instruments, such as- Ghono Baidya, Susir Baidya, Aaonodho Baidya and Toto Baidya. Materials including bamboo, wood, variety of metals (such as gold, silver, brass, bronze, iron etc) and also with the help of mud, they prepare some very special instruments which has global recognitions. Examples of some indigenously made instruments are Dhool, Khul, Muruli, Pepa, Doba, Sarenga, Honkho, Hutuli etc. Interestingly, these instruments are also used or have shown its influences in Marriage songs. One such example is mentioned below:

a) Dhool t sapor mariulal Ramchandra RaijoloiNomoskarakori.

b) PepaMuruliebajeghoneghone

Ramchandra Jygoloi jai

Sarendarbaboloi kune hikaigole

Kune aanidilehuna.

Folk Art:
Another facet of Folk literature is Folk Art which is continuing to show its richness till today. Folk Art reflects community strengths of creativity, activeness, artistic mind. In this prospect, Assamese community is not lacking behind. For instance, Assam has world famous KahorSilpo (bell-metal industry and its related art and craft). Assamese Weavers or Handlooms weaving their dreams in pieces of clothes which is also appreciated globally. Along with these, they also make other precious things like Koloh, Saki, Bahorbisoni, etc. with the help of these materials. These ideas have found its expression in Marriage songs in the following manner:

a) BahoreBisoniNanibaHahuAai, NanibaKahoreKahi

b) KharuLoiAhisuEtulaSunere Aru LoiAhisu Moni RuporetemateSendurloiahisu EkhonHatiDatorFoni

\section{Food Culture:}

Assam is an agro-based economy. As an agricultural economy, rice is the main food for its indigenous people. This is so because Paddy is easily available and cultivable and most of the land is used for Paddy cultivation. Assamese community makes various foods from paddy or rice like Chira, Xandoh, Pithaguri, Aakhoi, Hurum, etc. Then again special Pitha (idems prepared from rice powder) like TilPitha, Tel Pitha, GhilaPitha, HeshaPitha are the another important part of Assamese community. Items of Pitha prepared from rice powder are the main dishes in the Bihu festival of Assam. We found about various food in Assamese Marriage songs as mentioned below:

\section{Aakhoi-Saul-Sira PithaPoromanno Oi Ram bhag bota kori khao}

Geographical location of Assam is different from others. It has river based location where there is easy availability of various types of fish. Fish is also another part of Assamese food culture. In Assamese Marriage songs we found about fish as like:

HaheMasor hake 


\section{Pura masorpitika \\ Magurmasorkhorikatdia}

Understanding, Discussing and Preserving Assamese Biyanam: A unique element of Assamese Culture

Oral literature is an important carrier of culture, heritage and tradition of a particular cultural or linguistic community. It transforms and travels along with the changing currents of time. The 'biyanaam' or "wedding songs" sung in a traditional Assamese wedding ceremony is an integral part of Assamese culture. An Assamese wedding household is practically incomplete without these wedding songs that are sung throughout various ceremonies by the ladies present there. The women who usually sing these wedding songs are known as 'Ayotis'. The Ayotis sing these songs that have the ability to bring tears to the eyes of its listeners. However, with the changing course of times these wedding songs seem to have been extinct from our culture where only a handful of women know these songs. The blaring hindi songs in music players, DJ or live performances by singers have replaced the traditional wedding songs.

It is true that the traditional wedding songs have slowly vanished from Assamese weddings but efforts have been made to preserve them by means of publication in the form of books. Further, various researches have also been conducted upon them. They have also been published in the form of cassettes and in platforms like YouTube. Further, the various competitions have also immensely contributed towards its preservation. However, it cannot be denied that there is an inherent lack in all of these efforts. Education plays an important role in the preservation of a particular oral culture. Colleges and universities can organize various discussion circles and seminars and conferences that bring together minds from all around the world who can provide an aid towards the bringing out the different facets of these wedding songs.
Many other states also have this tradition of singing wedding songs in their wedding ceremonies. One can also conduct a comparative study between these wedding songs and Assamese 'Biyanaam'. These studies will also help us to discover the various unexplored facets of our wedding songs.

The different tribes of Assam have different wedding songs in their own dialects. An effort to collect as much as such wedding songs in order to publish them will also help us to preserve them. The academic institutions should conduct such exercises where a group of students should be assigned projects to collect these wedding songs found across Assam. This will increase their knowledge as well as help in the preservation of these wedding songs.

Government has also undertaken different initiatives that aim towards boosting the dissemination of oral folk songs. However, we also need to pay heed towards the textual publication and study of the 'Biyanaam'.

Folk literature is the product of society. Society comprises of people. Artists are also integral organs of the society. These artists should also extend their helping hands towards the preservation and dissemination of the wedding songs. A perfect example of such an initiative is the step taken by JyotiprasadAgarwala who immortalize wedding songs by revamping the famous folk song 'Gosegosepatidile' in the form of a wedding song. However, this is just an initiative. The ultimate responsibility lies upon the people who share the responsibility of preserving them.

\section{Conclusion:}

The wedding songs performed in the wedding ceremonies are an important part of Assamese culture. It is a carrier of Assamese culture and displays the rich attire, food habits and heritage of Assamese culture. Hence, this article has been written that sheds light upon its dissemination and preservation. Different initiatives undertaken by means of electronic and 
print media towards the preservation of the wedding songs should be acknowledged. However, these steps alone are insufficient. The educational institutions should step in to fill this void as they play an important role in this task of preserving the wedding songs. The various comparative studies as well as conferences can immensely contribute towards its preservation. The government schemes as well as the personal efforts of the artists can also aid this process. Thus, only unified efforts can preserve these wedding songs which are important part of the Assamese culture.

\section{Works Cited:}

[1] Barkataki, Annoda Devi (2004): Biyanaam, Jorhat, Barkataki Company.

[2] Boruah, Hunmoni (2015): AsomorBiyanaam:

EkBislesanatmokAdhayan, Dibrugarh University,Dibrugarh.

[3] Bori, Geetashree, and M. Neog Rupjyoti. "Emerging Trends in Woven Textile Fabrics Designs of Tribal Mising Community in Assam." International Journal of Applied and Natural Sciences (IJANS) 6.5 (2017): 7-14.

[4] BORAH, SANGEETA, and M. Borah. "Statistical evaluation of demographic disparities of two communities of Assam." International Journal of Applied Mathematics and Statistical Sciences 6.4 (2017): 99-106.

[5] Chungkrang, Lizamoni, Avarani Phukan, and Nabaneeta Gogoi. "A Study on Mishing Tribes and Their Traditional Costumes of Assam." International Journal of Textile and Fashion Technology (IJTFT) ISSN (P) (2016): 2250-2378.

[6] Das, MinakshiLahon (2014): Biyanaam, Guwahati, Bani Mandir, 1st publication.

[7] Gogoi, Lila AsomiyaLukoSahityarRuprekha, Dibrugarh, Students Emperium.
[8] Goswami, Prafulla Chandra (1993): BaroMahorTeroGeet, New Delhi, Sahitya Academy Rabindra Bhavan.

[9] Koch, Jibon Chandra (2006): SristirAnondomoiUtsobBiyaaruBiyanaam. Guwahati, Banimandir.

[10] SAIKIA, LOTIKA. "MIRRORING THE SOCIO-CULTURAL ETHOS OF ASSAMESE LIFE: A CRITICAL READING WITH SPECIAL REFERENCE TO ASSAMESE MARRIAGE SONGS." International Journal of English and Literature (IJEL) 9.4, Aug 2019, 19-24

[11] Sanjib, Khargharia, et al. "Parasitic load and haematobiochemical profile of cattle population of Joyhing area, North Lakhimpur, Assam." International Journal of Agricultural Science and Research (IJASR) 5.3 (2015): 85-88. 